\title{
Particularities of media systems in the West Nordic countries
}

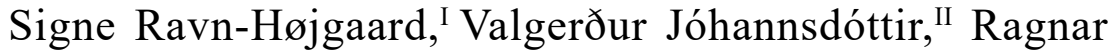

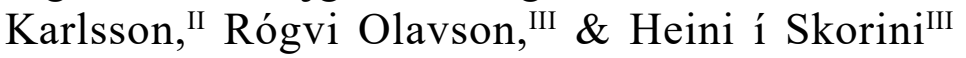 \\ I Department of Social Sciences, Economics and Journalism, University of Greenland \\ ${ }^{\text {II }}$ Faculty of Political Science, University of Iceland \\ ${ }^{\text {III }}$ Department of History and Social Sciences, University of the Faroe Islands
}

\begin{abstract}
This study compares the media systems of the West Nordic countries, namely the Faroe Islands, Greenland, and Iceland. All three countries are democratic welfare states with considerable institutional transfer from the larger Nordic countries. It is argued that the West Nordic media systems fit into the "Nordic model" when it comes to the perception of media as cultural institutions as well as the central role of public service media. On the other hand, the micro-size of the media systems in the West Nordic countries makes them vulnerable, and makes editorial independence more difficult compared with their larger Nordic neighbours. In particular, media outlets within these micro-size media systems seem more susceptible to clientelism, and journalists seem more inclined towards self-censorship. This article highlights how interplay between small size and distinct local factors shape the media system in each of the West Nordic countries.
\end{abstract}

Keywords: the Faroe Islands, Greenland, Iceland, comparative research, size

\section{Introduction}

This article examines the characteristics of the media systems in the three West Nordic countries: Iceland and the self-governing territories of Greenland and the Faroe Islands (the Faroes from here on). In comparison to their larger Nordic neighbours, the three West Nordic countries are Lilliputian. Limited internal markets make the media in small states vulnerable to external pressures, affect media regulation, and limit the possibilities of protecting and promoting media diversity (e.g., Lowe \& Nissen, 2011a; Meier \& Trappel, 1992; Puppis, 2009; Trappel, 1991, 2014). The three West Nordic countries share many structural peculiarities affecting their media systems in similar ways, such as threats to autonomy from interwoven political and business elites, fluctuations in their economies, and questions about whether professional integrity and expertise can be upheld in their labour markets. Historically, all three countries have a long-standing relationship with Denmark as dependencies, and all are in close relationship with the

Ravn-Højgaard, S., Jóhannsdóttir, V., Karlsson, R., Olavson, R., \& í Skorini, H. (2021). Particularities of media systems in the West Nordic countries. Nordicom Review, 42(S2), 102-123. https:// doi.org/10.2478/nor-2021-0020 
larger Nordic countries in political, cultural, and economic terms, reflected in their media systems and organisation of society. At the same time, the developmental route of their media systems varies due to small size, different infrastructure, and diverging social, economic, and political trajectories. In this article, we explore how these factors have moulded the media systems of the West Nordic countries. Our aim is to evaluate the extent to which the West Nordic countries share the features ascribed to the "Nordic model" as formulated in the theoretical literature, or if they can be said to constitute a group of their own.

The West Nordic countries have been almost invisible in comparative studies of media systems. Seldom notice has been paid to them from the outside, and when studied, the focus has almost entirely been on Iceland alone, mostly in bypass. Researchers have almost invariably assumed, without much elaboration, that the Icelandic media system shares most of the traits of the media systems in the larger Nordic countries (e.g., Lund, 2005, 2007; Nord, 2008; Syvertsen et al., 2014; Weibull, 2007), with Ohlsson (2015) as a notable exception. Local researchers have shown increased interest in questioning the features of the media systems in the three West Nordic countries. They have highlighted obvious structural and functional similarities with the media systems in the Nordic countries, though not without important reservations (e.g., Guðmundsson, 2018; Hussain, 2018; Jóhannsdóttir, 2019; Karlsson \& Broddason, 2018; Ravn-Højgaard, 2019).

The media systems in the West Nordic countries will be discussed in the context of Hallin and Mancini's (2004) comparative research of media systems in liberal democratic societies and Syvertsen and colleagues' (2014) conception of the Nordic media welfare state. Both models disregard factors that could differentiate systems due to country and market size. Here, we discuss the effects of size in the three countries and the more specific social and political evolution over time - and how the interplay between these factors has shaped and moulded their media systems.

This study is the first that compares the characteristics of the media systems in the West Nordic countries. There are, however, numerous difficulties involved when comparing social phenomena and cultural and historical traits between different national settings, as they are culture and nation bound and constructed (Livingstone, 2003). To avoid the danger of "simplification", the methodological approach applied can broadly be placed within the model of cross-national comparison labelled "nation as a unit of analysis" (Kohn, 1989: 20-21). This approach can be considered a mixture of the models "nation as an object of study" and "nation as a context of study", as we attempt to address and view the media systems in light of theories and number of measurable dimensions and variations between them (Livingstone, 2003).

Our research is an exploratory one. The source material is composed of secondary data, that is, research, reports, statistics, media accounts, and various other published material. It is, however, important to note that research in journalism and media is much more limited in the West Nordic countries than the larger Nordic countries. Statistics concerning the structure and development of the media industry are limited. A couple of reservations regarding the comparative method are also necessary. We analyse and compare the three West Nordic countries in the context of the Nordic media model as formulated in the theoretical literature, in order to evaluate to what extent the three West Nordic media systems share the features ascribed to the Nordic model. However, it is beyond the scope of this article to compare Iceland, the Faroes, and Greenland with 
each of the larger Nordic countries. Therefore, despite our use of the Nordic model as a theoretical tool, the comparison will be limited to the three West Nordic countries, though data on the four larger countries is on occasion included for analytical purposes. We also stress that we will not systematically compare all factors similarly in all three countries. On the basis of Hallin and Mancini's theoretical model, we emphasise what factors have shaped the media systems in the three countries, and in some instances, we highlight different factors in different countries, as some are unique to one country but irrelevant in others. We do not pretend to give all factors the same level of attention in all three countries. Instead, the purpose of the article is to highlight what factors have shaped the media in the three West Nordic countries and to provide an exploratory basis for further comparative studies.

\section{Theoretical framework}

Organisation of media and journalism is strongly influenced by the social systems, history, technology, specific political and cultural factors, and the interrelation between them. In Hallin and Mancini's (2004) typology of media systems, the larger Nordic media systems were all categorised as primary examples of the democratic corporatist model, with its "historical coexistence of commercial media, and media tied to organised and political groups, and by a relatively active but legally limited role of the state" (Hallin \& Mancini, 2004: 11). For elaborations of Hallin and Mancini's media system theory and further developments and criticism of it, see the introductory article of this issue.

Brüggemann and colleagues (2014) and Syvertsen and colleagues (2014) have argued that the media systems of the larger Nordic countries constitute a distinct group, characterised by similar historical trajectories of their media. Being small countries striving to preserve unique national cultures, their responses to pressures from technological change, liberalisation, and globalisation have been similar, and their media systems share many of the same organisational structures. Media policy in the Nordic region share four characteristics (Syvertsen et al., 2014): media is seen as a public good, freedom from editorial interference is a goal, cultural policy extending to the media, and a preference for consensual and durable policy decisions. This is manifested in high media consumption among all social groups, diverse media supply and variety in output, quick uptake of digital media, strong public service ethos and professionalisation, and consultancy and cooperation between the state, stakeholders, and citizens alike concerning all major decisions about arrangements and development in the field of the media. This justifies the labelling of the media systems in the Nordic countries as the Nordic media welfare state (Syvertsen et al., 2014). The West Nordic media systems were not included in any of these studies. In this article, we discuss how the micro-size of the West Nordics affects their media systems, whether their smaller size is a differentiating factor to the larger Nordic media systems, and whether the West Nordic media systems should be included in the group of Nordic media welfare states.

No clear and indisputable definition to distinguish between states due to size has yet been achieved, despite a long and extensive research tradition concerning the problems of small size, especially related to questions of economics and international political status (Thorhallsson, 2018). Different definitions are often confusing and contradict each other. The criteria used to distinguish between states or territories due to size vary from 
straightforward benchmarks of size of territory, population, or economy - as measured in the absolute or relational - to the more complex notion of self-perception of states, nations, and territories, or a mixture of both (Goetschel, 1998; Hängi, 1998; Puppis, 2009). Hence, "any effort to categorize countries as small and large is devilishly difficult" (Lowe et al., 2011b: 22). The concept of small state is always a relative term, and "the qualification of a state as small only makes sense in relation to larger states" (Goetschel, 1998: 14).

Accordingly, distinction between states as relating to their size can only be arbitrary (Lowe \& Nissen, 2011; Meier \& Trappel, 1992). Size should thus be considered a variable, rather than a constant, to be useful for analysis (Katzenstein, 1985). Size of population is the most used demarcation to distinguish between states in social and economic terms.

According to general international practice, the threshold of a population-based definition of small states is to set the upper limit at a population of 10-15 million for developed states, while the lower limit to separate small states from so-called microstates is 1 million inhabitants (Hängi, 1998). Despite certain ambiguity, usage of the term microstate would appear valid, because even the United Nations recognises that such an entity exists (Veenendaal, 2015).

Regardless of these shortcomings regarding size as an analytical concept for a comparative study, market size and the amount of available resources are inevitably important factors shaping national media systems (Puppis, 2009; Trappel, 2014). Puppis (2009) distinguishes four structural peculiarities of small media systems: 1) shortage of resources in form of capital, know-how, creativity, and media professionals; 2) small audience and small advertising markets making media production economically unviable; 3) dependence, as developments like commercialisation strongly affect small systems, but they are less able than large countries to influence these developments; and 4) vulnerability, as small states tend to conform to foreign media, foreign media products are present in their media markets, and there is the threat of takeover from foreign media companies. Hence, small states are inclined to an interventionist approach to their media policy (Puppis, 2009; Trappel, 1991, 2014) and tend to pursue corporatist policies to compensate for dependence, scarcity of resources, and economic and cultural vulnerability (Humphreys, 2012). However, these scholars categorise all the Nordic media systems as "small" or exclude nations with less than 100,000 inhabitants (Puppis, 2009).

Doyle argues (2002) that the resources available for the output of the media are inevitably constrained by size and wealth of the economy and overall levels of disposable income. Because of economics of scale, small countries can support fewer nationally produced media than larger countries. A number of elements must be taken into account when analysing the supply, diversity of suppliers, output, and pluralism of media markets, that is, technology, public policy, competitive behaviour, and options for innovation of new products. Irrespective of the nature of funding of the media, the effects of size, wealth, and level of resources in markets are inescapable and have a bearing on the level of pluralism. Support for the media through advertising and direct payments by consumers are closely related to consumer expenditure and economic wealth of the market. Similarly, subsidies and other state intervention for the enhancement of media supply and diversity is a function of the overall wealth of the economy and competing schemes for welfare expenditure. Other indicators of 
scale also have a bearing on media systems, such as geography and typography, level of urbanisation, and language.

In the following, we illustrate how the West Nordic countries are marked by their smallness and discuss the common - and different - social, economic, and political factors that impact their media systems.

\section{The West Nordic micro-cosmos}

The West Nordic countries share many traits with their Nordic neighbours, as their histories have been closely interwoven for centuries. The institutional framework, laws, and political systems are similar to those of the larger Nordic countries, and all three are committed to the Nordic welfare approach. As in the larger Nordic countries, the West Nordics have multiparty systems with numerous parties competing in national elections, and coalition governments are the norm. Their administrative systems are, however, weak, due to their small size and late development of rational legal authority (Ackrén, 2015; Kristinsson, 2012; Winther, 2004). Instead of consensus politics, which have characterised the Scandinavian countries throughout the post-World War II era (Hallin \& Mancini, 2004), the political fora in the West Nordics is better described as adversarial, and majority rule is the norm in the parliaments (Ackrén, 2015; Hardarson, 2008; Wang, 1989).

The issue of independence from Denmark has been an important dimension forming the political landscape in all the three countries (e.g., Ackrén 2019, Ackrén \& Lindström, 2013; Hardarson, 2008), although in different ways and at different times. The development of the mass media in the West Nordics is intimately connected to the evolution of the political systems and a catalyst for political change and growing independence resulting in either home rule (Iceland in 1904, the Faroes in 1948, Greenland in 1979) or full statehood (Iceland in 1944).

The West Nordic countries all have unique languages, which can be claimed to be the prime markers of national identity in all of them (Vikør, 2000). Nationalist movements have put their mark on the political culture in all the West Nordic countries. Independence and state-formation have shaped the main cleavages between the political parties in these countries, whereas the media have played an influential role of dissemination and clarifying contesting arguments (Loukacheva, 2007; Wang, 1989). This is particularly clear in the Faroes and Greenland, where state-formation has not materialised (Grímsson, 1978; Wang, 1999), but less so in Iceland of today, as state-building and independence have been settled for some time and replaced by other concerns and issues.

The total population of the West Nordic countries is less than half a million - only a fraction of the population of each of the large Nordic countries. In terms of GDP, the larger Nordic countries are 100-215 times larger than the Faroes and Greenland, and 10-20 times larger than Iceland. In terms of affluence, all the Nordic countries rank among the top 20 economies in the world, measured in terms of GDP per capita, as shown in Table 1. In Greenland, subsidies from Denmark make up a sizeable part of the public budget (approximately 55\%). Greenland is also different from the two other West Nordic countries due to the large public sector with many government-owned corporations. 
Table 1 Populations and economies in the Nordic countries

\begin{tabular}{lccccc}
\hline & $\begin{array}{c}\text { Surface area } \\
\text { (thousand } \\
\text { per km2) }\end{array}$ & $\begin{array}{c}\text { Population } \\
\text { (thousand) }\end{array}$ & $\begin{array}{c}\text { GDP (million } \\
\text { USD) }\end{array}$ & $\begin{array}{c}\text { GDP per } \\
\text { capita (USD) }\end{array}$ & $\begin{array}{c}\text { GDP per } \\
\text { capita (rank) }\end{array}$ \\
\hline Faroes & 1 & 49 & 2,689 & 55,818 & 18 \\
Greenland & 2,166 & 56 & 2,707 & 48,179 & 25 \\
Iceland & 103 & 354 & 25,878 & 73,190 & 12 \\
Denmark & 43 & 5,797 & 355,675 & 61,355 & 16 \\
Finland & 338 & 5,518 & 276,743 & 50,153 & 22 \\
Norway & 385 & 5,314 & 434,167 & 81,702 & 7 \\
Sweden & 450 & 10,183 & 556,086 & 54,609 & 19 \\
\hline
\end{tabular}

Comments: Amounts refer to 2018, otherwise most recent available data (in current USD).

Source: The World Bank, n.d.

In sum, the comparison in Table 1 indicates that the West Nordic countries share some economic, geographical, and demographical features besides the history as dependencies of Denmark. Therefore, we will explore how these factors affect the media systems in the three countries and whether they can be perceived as Nordic media welfare states or as a group of their own.

\section{Structure of the media markets}

The tiny populations of the West Nordic countries might suggest a natural monopoly, as diseconomies of scale abound in their media markets, but foreign observers have been surprised by the varied media diet these markets supply, particularly in Iceland and the Faroes (Noam, 1991; Ørberg, 1984).

The media in the West Nordic countries have come under increased pressure from amplified flow of media content from international media service providers, accompanied by audience and revenue drain of the domestic media, as manifested in newspaper deaths, commercialisation, and poor economic performance of the media in general (Dalsgarð, 2002; Guðmundsson, 2018; Jóhannsdóttir \& Ólafsson, 2018; Karlsson, 2004; Karlsson \& Broddason, 2018; Ravn-Højgaard, 2019). The West Nordic countries have severely limited capability to react and maneuver against these changes. Often, there is no other option available other than making "the best out of dependency" and adopting new technology and responding to increased international media flow by "flexible adjustment", as Trappel (1991) claims for media policy dilemmas of small states in general.

Similar to the larger Nordic countries (Syvertsen et al., 2014), media is conceived as a cultural institution vital for the protection of the national language and culture. National sentiments as far as the media are concerned are most apparent in questions about provision of nationally produced content on television. In all the countries, the government uses various measures to encourage domestically produced programming. For example, Iceland has a duty of translation and dubbing of foreign television programmes.

In the Faroes and Iceland, the markets have been afflicted by newspaper deaths, especially since the turn of the century. Dailies are no longer published in the Faroes, and presently, only two are published in Iceland, compared to six in the 1980s and 1990s. 
Signe Ravn-Højgaard, Valgerður Jóhannsdóttir, Ragnar Karlsson, Rógvi Olavson, \& Heini í Skorini

Greenland has never had a daily, and there has been a de facto monopoly in the national press since 2010, when the two national papers became jointly owned. Table 2 depicts the press markets in the West Nordic countries from 1950-2018. It highlights the small size of the press in all countries and illuminates their differences owed to the very limited size of the markets and difficulties involved with distribution, as in Greenland, with fewer titles and much lower circulation per capita.

Table 2 Newspapers in the West Nordic countries, 1950-2018 (daily and non-daily titles and circulation)

\begin{tabular}{|c|c|c|c|c|c|c|c|c|}
\hline & 1950 & 1960 & 1970 & 1980 & 1990 & 2000 & 2010 & 2018 \\
\hline \multicolumn{9}{|c|}{ Number of titles } \\
\hline \multicolumn{9}{|l|}{ Faroes } \\
\hline dailies & 0 & 0 & 0 & 0 & 1 & 2 & 1 & - \\
\hline non-dailies & 6 & 6 & 6 & 7 & 8 & 3 & 3 & 3 \\
\hline \multicolumn{9}{|l|}{ Greenland } \\
\hline national non-dailies & 0 & 0 & 0 & 2 & 2 & 2 & 2 & 2 \\
\hline \multicolumn{9}{|l|}{ Iceland } \\
\hline dailies & 5 & 5 & 5 & 6 & 6 & 3 & 2 & 2 \\
\hline non-dailies & 9 & 10 & 6 & 9 & 18 & 19 & 21 & 18 \\
\hline \multicolumn{9}{|c|}{ Circulation in thousands } \\
\hline \multicolumn{9}{|l|}{ Faroes } \\
\hline dailies & 0 & 0 & 0 & 0 & 6 & 17 & 9 & 0 \\
\hline non-dailies & 11 & 16 & 20 & 35 & 30 & 11 & 18 & 12 \\
\hline \multicolumn{9}{|l|}{ Greenland } \\
\hline national non-dailies & 0 & 0 & 0 & 9 & 10 & 9 & 4 & 4 \\
\hline \multicolumn{9}{|l|}{ Iceland } \\
\hline dailies & 46 & 57 & 68 & 88 & 96 & 91 & 130 & 119 \\
\hline non-dailies & .. &.. & .. & .. & 56 & 57 & 231 & 136 \\
\hline \multicolumn{9}{|c|}{ Circulation per 100 inhabitants } \\
\hline \multicolumn{9}{|l|}{ Faroes } \\
\hline dailies & 0 & 0 & 0 & 0 & 13 & 37 & 18 & 0 \\
\hline non-dailies & 36 & 47 & 52 & 80 & 64 & 23 & 37 & 24 \\
\hline \multicolumn{9}{|l|}{ Greenland } \\
\hline national non-dailies & 0 & 0 & 0 & 18 & 18 & 15 & 8 & 7 \\
\hline \multicolumn{9}{|l|}{ Iceland } \\
\hline dailies & 32 & 32 & 33 & 38 & 38 & 32 & 41 & 33 \\
\hline non-dailies & .. & .. & .. & .. & .. & 20 & 73 & 38 \\
\hline
\end{tabular}

Comments: Paid-for and free papers included. Dailies = newspapers issued 4 times or more per week. Non-dailies $=$ newspapers issued $1-3$ times per week (.. = data not available).

Source: Dalsgarð, 2002; Karlsson, 2008; Paulsen et al., 2018; Ravn-Højgaard, 2019; Statistics Faroe Islands, n.d.; Statistics Iceland, n.d.; Thomsen \& Søllinge, 1991 
Newspaper circulation has declined for decades but has accelerated with the increasing competition brought about by digital media. In Iceland, a somewhat uniquely strong position of free papers (Bakker, 2013) has not even been able to reverse this trend.

Broadcasting commenced in the West Nordic countries at different times and circumstances, as discussed below. In the three countries, the outlets of private news media are few, and the public service media (PSM) play an important role. Radio was introduced in Iceland by private initiative in 1926, but the state was soon granted broadcasting monopoly, and the public Ríkisútvarpið (RÚV-Radio) went on the air in 1930. This monopoly was abolished in 1986. Since then, a number of private radio channels have been established, mainly broadcasting pop music.

Radio emerged in Greenland with news transmissions via radio telephony in 1926. The broadcasts became regular in 1942 when the newspaper editors started broadcasting during World War II, when Greenland was cut off from Denmark. The broadcasts of what today is called Kalaallit Nunaata Radioa (KNR), the PSM-station, commenced in 1958. The first private radio stations in Greenland were founded in the late 1980s, and today, there are two commercial pop channels on air. A dozen stations, most operated by non-profit organisations, also transmit more or less regularly in the various towns and villages.

The Faroes was the last of the Nordic countries to introduce radio when the public Útvarp Føroya (ÚF) was established in 1957. Hitherto, the Faroese were accustomed to listening to foreign channels, mainly Norwegian and Danish PSM (Andreassen, 1992). Public Faroese television emerged in 1983, and in 2005, television and radio merged into Kringvarp Føroya (KvF). Private radio emerged in the Faroes in 1999. Currently, there are three private radio channels with limited resources, compared with the relatively strong position of the public service channel.

In all three West Nordic countries, introduction of PSM television was initiated in order to prevent external influences, as has been noted in many developing countries (Katz \& Wedell, 1977). In Iceland, national television was introduced in 1966, largely in response to transmissions from the American naval base in Keflavík, whose broadcasts became widely receivable in the capital region in the early 1960s. While many welcomed the transmissions, others saw the broadcast "as nothing less than an infringement by a foreign power in the cultural affairs of a sovereign country" (Karlsson \& Broddason, 2010: 223). This hastened the foundation of RÚV-TV, probably by several years. Private television began in Iceland in 1986 with the abolition of the broadcasting monopoly. Presently, there are seven private television stations, of which one is a general-interest channel and the others are special-interest channels: sports, religion, local, talk, and so on.

Television was introduced in the Faroes and Greenland by private initiatives in the 1970s, where illegally taped videos were shipped by individuals in Denmark and aired in private $\mathrm{TV}$-associations that eventually started their own restricted programme production (for a history of television in Greenland, see Rygaard, 2016). Public television emerged in Greenland in 1982 and, as noted, in the Faroes in 1983 (Poulsen, 1980, 1995). In Greenland, there are a few private local television channels in operation offering some local news, though irregularly. They mainly distribute satellite-TV, financed mostly by member fees. In the Faroes, there is still only one Faroese television channel, operated by KvF. 
Similar to the larger Nordic countries, the West Nordic countries' PSM have a strong position in the media market, equally as radio and television are concerned (see Table 3). In Greenland, KNR's radio market share of total listening time among the population was 82 per cent, which is by far the highest for public radio in the Nordic countries. In television, KNR had 54 per cent of television audience market share.

Table 3 Public service broadcasting audience shares in the Nordic countries, 2019 (per cent)

\begin{tabular}{lccc}
\hline & Organisation & Radio & TV \\
\hline Faroes & KvF &.. &.. \\
Greenland & KNR & 82 & 54 \\
Iceland & RÚV & 50 & 67 \\
Denmark & DR & 77 & 36 \\
Finland & YLE & 49 & 44 \\
Norway & NRK & 65 & 39 \\
Sweden & SR/SVT & 70 & 35 \\
\hline
\end{tabular}

Comment: .. = data not available.

Source: KNR, 2020; Nordicom, n.d.-a-b

In Iceland, RÚV-Radio had 50 per cent market share, which is the lowest share of PSM radio within the Nordic countries, along with YLE in Finland. The market position of RÚV in television is unequally high in Nordic comparison, as RÚV-TV retained 67 per cent market share in the autumn of 2019. Comparable information is not available for $\mathrm{KvF}$, but according to a Faroese survey from 2017, almost 60 per cent of the respondents said they listened to public service radio on a daily basis; for the private radio stations, the number was approximately 15 per cent or less (Lóður, 2017).

The limited programming capacity in the West Nordic countries is mainly used for producing informative content, news, and sports, and to a lesser degree programmes for children, while fiction is almost exclusively imported. Even in Iceland, with three times the money devoted to public television (see Table 4), production for television, especially of more expensive programmes, drama, and series, is highly restricted. The average daily local domestically produced programmes on RÚV-TV is 6.5 hours (RÚV, 2019), while the daily new output on $\mathrm{KvF}$ is less than 2 hours (KvF, 2018) and on KNR, 3.1 hours (KNR, 2020).

Distribution, access, and use of information communication technology (ICT) and new digital media differs between the West Nordic countries. Whereas access to and use of ICTs is almost universal in the Faroes and Iceland (comparable to that in the larger Nordic countries), the uptake in Greenland has been slower, due to a less developed infrastructure (Ravn-Højgaard, 2019). The media in the West Nordic countries have strong online presence, offering various content, streaming and downloading of content, as well as active social media accounts. Additionally, in all the West Nordic countries, there is a plethora of websites, maintained by individuals and various other actors, mostly covering sports and entertainment. In all three countries, the most accessed and used online websites are owned by the larger media actors, signifying high concentration 
and consolidation online, as in the traditional media markets (for the Faroes, see Lóður, 2017; for Iceland, see Gallup, 2020).

Newspaper consumption has declined with readers moving online. Obtaining a clear overview of the digital media markets in the West Nordic countries is difficult, due to lack of comparable data. Recent research on news consumption in Iceland (Jóhannsdóttir, this issue), illustrates that online sites are Icelanders' most popular source of news, and among those aged 45 and younger, social media comes second. In the Faroes, online news consumption is generally high, and the private news websites outmatch the public service website. So, while public service is much stronger in radio and television, it is weaker with regard to online news consumption (Lóður, 2017). In Greenland, 56 per cent of the population uses the Internet daily, and 71 per cent use television daily in 2019 (KNR, 2020).

\section{Role of the state}

The PSM organisations in the West Nordic countries have played a dominant role in the media market (Jóhannsdóttir \& Ólafsson, 2018; Paulsen et al., 2018). That demonstrates a high degree of state involvement in their media systems, a characteristic of the democratic corporatist countries (Hallin \& Mancini, 2004) and Nordic media welfare states (Syvertsen et al., 2014). As Trappel (2014) and Puppis (2009) argue, small states are prone to regulate and support the media to a large extent, as they are considered important cultural and democratic institutions, rather than merely businesses. Therefore, small states often play an active role in ensuring and stimulating media supply and diversity to counterweigh otherwise dire effects of severely restricted financial resources. Similar to the larger Nordic countries, PSM organisations are perceived as vital for the preservation of local language and culture in light of globalisation (Syvertsen et al., 2014), and they are recognised as cultural institutions that provide content that cannot otherwise be provided in these very small markets.

The West Nordic countries have modelled their legal framework regarding PSM on the Danish model, and in all three countries, a public service remit is negotiated every fourth year. Table 4 highlights the differences between the PSM organisations in the West Nordic countries and those in the larger countries, as well as the internal differences between the PSM organisations in the Nordic micro-societies. 
Signe Ravn-Højgaard, Valgerður Jóhannsdóttir, Ragnar Karlsson, Rógvi Olavson, \& Heini í Skorini

Table 4 Public service media organisations in the Nordic countries, 2017-2018 (revenue and full-time positions)

\begin{tabular}{lrrrcr}
\hline & \multicolumn{3}{c}{ Revenue (thousand EUR) } & $\begin{array}{c}\text { Public financing } \\
\text { (\%) }\end{array}$ & $\begin{array}{c}\text { Full-time } \\
\text { positions }\end{array}$ \\
& \multicolumn{1}{c}{ Total } & Public & Market & & \\
\hline Faroes (KvF) & 10,053 & 8,359 & 1,694 & 83 & 95 \\
Greenland (KNR) & 9,844 & 9,096 & 748 & 92 & 92 \\
Iceland (RÚV) & 47,989 & 30,714 & 17,275 & 64 & 260 \\
Denmark (DR) & 548,639 & 496,346 & 52,293 & 90 & 2,699 \\
Finland (YLE) & 472,265 & 461,771 & 10,494 & 98 & 3,333 \\
Norway (NRK) & 583,101 & 549,094 & 34,007 & 94 & 3,419 \\
Sweden (SR/SVT/UR) & 768,285 & 734,960 & 33,325 & 96 & 4,617 \\
\hline
\end{tabular}

\begin{tabular}{lcccc}
\hline & \multicolumn{3}{c}{ Revenue (EUR per capita) } & $\begin{array}{c}\text { Full annual PSM } \\
\text { licence fee or tax (EUR) }\end{array}$ \\
& Total & Public & Market & \\
\hline Faroes (KvF) & 205 & 171 & 35 & $80-241$ \\
Greenland (KNR) & 176 & 163 & 13 & * \\
Iceland (RÚV) & 138 & 88 & 50 & 335 \\
Denmark (DR) & 549 & 496 & 52 & $50-143$ \\
Finland (YLE) & 472 & 462 & 10 & 308 \\
Norway (NRK) & 583 & 549 & 34 & 243 \\
Sweden (SR/SVT/UR) & 768 & 735 & 33 & \\
\hline
\end{tabular}

Comments: Revenue in current prices.

*direct government funding

Source: Annual accounts and financial statements of the PSM organisations, authors reworking

Hallin and Mancini (2004) argue that similar institutional arrangement in broadcasting governance can lead to very different results in majoritarian democracies than in consensual democracies. Consensual governments are predominant in the four larger Nordic countries, and their PSM governance is characterised by a strong separation between politics and broadcasting (Hallin \& Mancini, 2004; Moe \& Mjøs, 2013). However, as mentioned, the West Nordic countries are characterised by majoritarian rule, and according to Humphreys (1996: 11) "we might expect the publicly-owned media to be more vulnerable to capture by the dominant political tendency". Table 5 shows the institutional arrangement of broadcasting governance in the West Nordic countries. 
Table 5 Appointment of public service media boards in the West Nordic countries

\begin{tabular}{lccl}
\hline & Organisation & Members & Appointment \\
\hline Faroes & KvF & 7 & $\begin{array}{l}\text { Four members appointed by the political parties } \\
\text { represented in the parliament, two by the minis- } \\
\text { ter, and one by the staff of KvF. }\end{array}$ \\
Greenland & KNR & 6 & $\begin{array}{l}\text { Head of board and one member appointed by } \\
\text { the government, three others upon recom- } \\
\text { mendations by the University and The Cultural } \\
\text { Association, and one by the staff of KNR. }\end{array}$ \\
Iceland & RÚV & $\begin{array}{l}\text { The governing board of RÚV is elected by } \\
\text { parliament by proportional representation, and } \\
\text { one is appointed by the staff of RÚV without } \\
\text { voting right. }\end{array}$ \\
\hline
\end{tabular}

Source: Faroese Law-Site, 2006; Inatsisiliorneq Lovgivning, 2004; National Parliament of Iceland, 2013

Icelandic scholars have argued that RÚV has enjoyed less institutional autonomy than other Nordic PSM companies (Jóhannsdóttir \& Ólafsson, 2018; Karlsson \& Broddason, 2018) and that the system of PSM governance resembles more what Humphreys (1996) labels the "government model" than the professional model which Hallin and Mancini (2004) claim is prevalent in the Scandinavian countries. The relations between politics and broadcasting have not been systematically studied in the Faroes. In Greenland, the political influence on PSM has diminished since 1980s, as distance between the political system and the PSM has been increasingly institutionalised. However, as argued by Ravn-Højgaard in this issue, the PSM budget is negotiated every year as part of the finance bill, and as there is no long-term media policy, changes can happen quickly.

From the outset, the PSM organisations in Iceland and the Faroes were financed by licence-fees, and later by a special tax, whereas KNR has always been funded directly from the public budget. In all three countries, advertisements are allowed in the PSM (see Table 6). The share of revenue coming from advertising, however, varies, from 34 per cent in RÚV to 8 per cent in KNR to 0 per cent in KvF (see Table 4). In the Faroes, advertising is allowed; however, its revenue is not used to finance the PSM, but goes directly into the state budget in order to prevent unfair competition with private media. 
Signe Ravn-Højgaard, Valgerður Jóhannsdóttir, Ragnar Karlsson, Rógvi Olavson, \& Heini í Skorini

Table 6 State involvement in media in the Nordic countries (allowances and restrictions)

\begin{tabular}{|c|c|c|c|c|c|c|c|}
\hline & Faroes & $\begin{array}{l}\text { Green- } \\
\text { land }\end{array}$ & Iceland & Denmark & Finland & Norway & Sweden \\
\hline $\begin{array}{l}\text { Direct subsidies } \\
\text { to private media }\end{array}$ & Yes & Yes & No & Yes & Yes & Yes & Yes \\
\hline $\begin{array}{l}\text { Indirect subsidies } \\
\text { to private mediaa }\end{array}$ & Yes & $\mathrm{No}^{\mathrm{c}}$ & Yes & Yes & Yes & Yes & Yes \\
\hline $\begin{array}{l}\text { Limits to media } \\
\text { ownership }\end{array}$ & No & No & No & No & No & Yes & No \\
\hline $\begin{array}{l}\text { Advertisements } \\
\text { allowed in public } \\
\text { service radio } \\
\text { \& TV }\end{array}$ & Yes $^{d}$ & Yes & Yes & No & No & No & No \\
\hline $\begin{array}{l}\text { Advertisements } \\
\text { allowed on the } \\
\text { public service } \\
\text { web }\end{array}$ & No & No & No & No & No & No & No \\
\hline
\end{tabular}

${ }^{a}$ For example, lower VAT rate on subscriptions and sale to users.

${ }^{\mathrm{b}}$ That is, other than restrictions and limits set out in competition laws.

' However, the public sector is the main advertiser in the private media.

${ }^{\mathrm{d}}$ Advertisements allowed but revenue goes to the state budget.

Source: Nord, 2008; with additions from the authors

Historically, neither the private media in Iceland nor the Faroes have received government funding. In Iceland's case, there has been near unanimous agreement across the political spectrum that private media should be solely in the hands of the market (Karlsson, 2004), and Icelandic media has been among the least regulated in Europe (Hardarson, 2008). However, increasing global competition and economic hardship of national media has led to policy changes. Media subsidies were introduced in the Faroes in 2017. A bill proposing public support for private media was tabled in the Icelandic parliament in late 2019, but had not been passed as of November 2020 (see Table 7).

The possible introduction of private subsidies in the Faroes and Iceland can be seen as a response to growing competition from foreign media and loss of advertising revenue to global tech giants, due to globalisation and digital technology (Mattoni \& Ceccobelli, 2018; Nechushtai, 2018). In Greenland, the media has always been supported, initially as government media, and later as private media (Ravn-Højgaard, this issue). The dominating role of the Greenlandic public sector influences the advertisement market, as the government becomes the most important advertiser, and advertisement policy can therefore be perceived as part of the media policy. 
Table 7 Media subsidies to private media in the West Nordic countries

\begin{tabular}{ll}
\hline & Subsidies (thousand EUR) \\
\hline Faroes & \\
$\quad$ Subsidies introduced in 2017. Platform neutral. & 270 \\
Greenland & Radio \& TV: 250 \\
Long tradition of state funding. Platform specific & Press: 330 (as of 2020) \\
support to print media. & \\
Iceland & \\
$\quad$ Bill introduced in Parliament in 2019 proposing sub- & \\
sidies to private news media. Platform neutral. & 2,890 (as proposed) \\
\hline
\end{tabular}

Comments: All amounts are rounded to the nearest decimal (current EUR).

Source: Faroese Law-Site, 2017; Menntamálaráðuneytið, 2019; Ravn-Højgaard, this issue

In sum, all three countries have strong PSM institutions, but only Greenland has a tradition of supporting private media, while Iceland and the Faroes have diverged from the Nordic model. However, with the recent introduction of subsidies to private media, the two countries are moving closer towards the Nordic media welfare state ideal.

\section{Political parallelism}

In the Faroes and Iceland, the early press was intrinsically connected to growing nationalist sentiments and the formation of political parties (Dalsgarð, 2002; Friðriksson, 2000). The political parties and their aligned newspapers were defined in contrast to each other by their view on the relationship with Denmark (pro-union or anti-union). However, after Iceland became a sovereign state in 1918, class politics took over. The dominant newspapers in both countries were firmly entrenched in party politics, in terms of ownership as well as recruitment of key personnel, editors, managers, and even journalists (Dalsgarð, 2002; Karlsson \& Broddason, 2018). Only recently, in the 1990s, has the formal link between papers and parties disappeared in the Faroes and Iceland. Since then, the newspapers have had to rely on their performance in the market (Dalsgarð, 2002; Karlsson, 2004) and financial backing from benefactors with vested interests in businesses and political agendas (Karlsson \& Broddason, 2018). The reasons the demise of the party press happened much later in these two countries compared with the larger Nordic countries owes undoubtedly much to late development of the consumer market, and hence limited advertising revenue. Also, changes in the media, increased professionalism among journalists, and political changes more generally had an effect (Karlsson \& Broddason, 2018).

In this regard, Greenland differs from Iceland and the Faroes, as the press did not evolve along the political dimensions of independence or class politics. Rather than party affiliation, close ties between the government and the media have shaped Greenland's media landscape (see Ravn-Højgaard, this issue; Stenbaek, 1992). The first national paper was initiated by Danish colonial administrators a century before the formation of political parties, which emerged prior to the introduction of home rule in 1979.

As the press in Iceland and the Faroes detached itself from the political parties, and the Greenlandic papers detached themselves from the government - new sources of income have been necessary. As elsewhere, this has led to an increasing commercialisation 
of the media (Dalsgarð, 2002; Guðmundsson \& Kristinsson, 2019; Jóhannsdóttir, 2020), and while political parallelism has declined in the form of party affiliation, other forms of commercial and political interests have entered the media scene. The news media have professed to journalistic ideals such as autonomy, political neutrality, and objectivity, at least according to their own self-perception, and have sought to appeal to a broader and more diverse public (regarding Iceland, see Guðmundsson, 2012; Guðmundsson \& Kristinsson, 2019). However, while political parallelism - understood as formal links between parties and newspapers - has declined, it does not mean that political parallelism in a wider sense has vanished. Guðmundsson (2012: 528) argues that the historical proximity of political parallelism in Iceland, a relatively recent professionalisation of journalists, an unregulated media environment, and an "extreme ownership concentration of the media, where ownership powers and political parties become mixed with each other" have paved the way for the development of a "political commercial media system". According to Ohlsson and Facht (2017: 93), the Icelandic media market is "characterised by a comparatively tight bond between the political sphere and the domestic enterprise sector" and that links with external stakeholders contribute "to the relationships in the media market being more problematic than they are in the other Nordic countries". In this regard, it might be more relevant to talk of clientelism rather than political parallelism.

Clientelism is associated with instrumentalisation of the media, that is, the control of the media by external actors seeking political or economic influence (Hallin \& Mancini 2004). Examples indicating instrumentalisation can be found in all three West Nordic countries. In Iceland, the owners of Árvakur - the publisher of the oldest newspaper in the country and the most read online news site - are investors with interests in the fishing industry who acquired the company in 2009, purportedly to intervene in the world of politics (Jóhannsdóttir \& Ólafsson, 2018; Karlsson \& Broddason, 2018). In the Faroes, the largest shipping company is the largest co-owner of one national news website. The small size of these countries inflates the danger of clientelism, as almost everyone knows someone who knows someone in the right places (Kristensen et al., 2020; Kristinsson, 2012).

\section{Professionalism}

Professionalism is associated with autonomy, a public service orientation, and distinct professional norms (Hallin \& Mancini, 2004). All three West Nordic countries have codified professional norms and ethical rules for the journalism profession. Greenland and the Faroes have adopted the Danish press ethical codes, which are widely accepted as ideals for the profession. Professional norms are also widespread among journalists in Iceland. However, there are factors indicating that journalistic professionalism is weaker in the West Nordic countries, compared with the larger Nordic countries where "respect for journalistic autonomy" is more "deeply held" (Strömbäck et al., 2008: 19).

The smallness of the West Nordic societies influences journalistic professionalism in several ways. Journalists are not anonymous, and they inevitably meet their sources in the supermarket or at family gatherings. Journalists develop different strategies to cope with this in small societies. One strategy is to try to maintain a strict division between private relations and professional relations with sources, and another strategy 
is self-censorship (Hussain, 2018; Porláksson, 2015). Two-thirds of journalists in the Faroes report having been on the receiving end of unfriendly pressure because of their job, while one-fifth report having been directly threatened, physically or otherwise (Føroysk Miðlafólk, 2017). Such personal consequences may lead journalists to seek other professions (Rask, 2017). It can also lead to other sanctions, such as withdrawal of advertisers (Weihe, 2017). In small societies, advertisers are fewer, which makes the media vulnerable to such sanctions, and can undermine journalistic autonomy. The instrumentalisation of the media, apparent particularly in the Faroes and Iceland, as discussed above, has the same effect. Frequent libel suits against journalists can also be interpreted as an indicator of a weak profession. Faroese journalists have been sued in libel cases, which, according to a former editor-in-chief at $\mathrm{KvF}$, generates self-censorship among journalists (Weihe, 2017). In Iceland, the number of libel cases filed against journalists has increased in the last decade. At the same time, the number of complaints to the Journalist Union Ethics Committee have decreased, and they receive relatively fewer complaints about editorial content than their counterparts in the larger Nordic countries (Axelsson \& Gylfadóttir, 2015).

Moreover, small communities with strong social control may entail a weak deliberative culture. According to Paul Krarup (2017), editor-in-chief of the Greenlandic newspaper Sermitsiaq,

[no sources] dare to go up against politicians or officials who hold positions of authority [...]. Those who know anything about a case do not participate in the debate with factual information. Hence, large part of the debate will often build on wrong premises [translated].

In Iceland, a quarter of journalists have a journalist education, and just over two-thirds of journalists have either a bachelor's or a master's degree, according to a survey (Kolbeins, 2012). In the Faroes, just under half of journalists responding to a survey in 2017 had specialised in journalism, whereas 70 per cent had a university education (Føroysk Miðlafólk, 2017). In Greenland, as of August 2020, most journalists working in KNR have a bachelor's degree in journalism.

While Iceland and Greenland offer a degree in journalism, the Faroes does not - most of Faroese journalists are educated in Denmark. However, the Greenlandic media relies on journalists imported from Denmark, as the media are not able to hire enough local journalists. In February 2020, between one-third and one-half of the journalists and editors in the newsrooms at Sermitisiaq.AG and KNR were educated in Denmark and had no prior knowledge of Greenlandic. The same is not the case in the Faroes, where practically all journalists speak Faroese.

Staff turnover is high in the media in all the West Nordic countries. It can largely be ascribed to journalists moving to better-paid jobs, for example, in the public sector. In Greenland, the turnover is also influenced by the large proportion of especially Danish journalists moving back to Denmark. Historically, layoffs have been very few, and vacant positions are common. In Iceland and the Faroes, on the other hand, journalists' job security has decreased, and layoffs have been frequent.

Changes in the digital age have undermined the media business models everywhere and led to increasing competition, which has implications for job security and autonomy of journalists (see, e.g., Mattoni \& Ceccobelli, 2018; Nechushtai, 2018; Witschge et al., 
2016). This applies to the West Nordic countries, but little is known about the possible impact this has had on the practice and values in journalism in these countries. Jóhannsdóttir (2020) observes that commercialisation has increased in Icelandic online news, and journalists have incorporated the practice of instant publishing, as noted elsewhere. Guðmundsson and Kristinsson (2019: 17) conclude that media companies have "assumed the power to define formal journalistic principles to fit their interests". Guðmundsson's (2015) findings indicate that the discourse on social media has greatly influenced the news and news values of journalists and their tendency for self-censorship. Comparable research is not available in the Faroes or Greenland.

\section{Conclusion}

Media research has so far overlooked very small countries, so-called micro-nations, like Greenland, Iceland, and the Faroe Islands. Although part of the Nordic region, they have rarely been included in comparative media system research. Neither the Faroes nor Greenland are included in Syvertsen and colleagues' (2014) study of the Nordic media model. Iceland is included, but without adequate data.

We argue that the West Nordic countries share many traits with their larger Nordic neighbours: they are all democratic welfare states and their media systems are similar in many ways. As in the Nordic countries (Syvertsen et al., 2014), the media has played an important role in the development of these societies. All three countries have large PSM organisations perceived as central cultural institutions aiming to preserve language and national identity. However, as all national media systems are shaped by specific national and local circumstances (Flew \& Waisbord, 2015), the West Nordic media systems diverge in several respects from each other, as well as from their larger Nordic neighbours.

We suggest that the Nordic model should be supplemented with a dimension taking size into account, which would include the West Nordic media systems. Most research on the implications of size on media systems (e.g., Trappel, 2014) would group all Nordic media systems as small. We argue that smallness should not be treated as a constant, but as an independent variable, as being micro-size has more amplified and sometimes different consequences on the media systems. Limited internal media markets are highly vulnerable to external pressures. Similar to the rest of the Nordic region, this is countered by an active media policy maintaining a supply that would not have been possible if left to market forces alone (Syvertsen et al., 2014). However, contrary to what would be expected - and contrary to the Nordic media welfare state model - the authorities in the Faroes and Iceland have played a reluctant role in the private media market, and the Icelandic media market has been one of the least regulated in Europe (Hardarson, 2008). Only recently have private media subsidies been considered and, if passed, will make the Icelandic media system more like its Nordic counterparts (Jóhannsdóttir, 2020). In Greenland, on the other hand, the public sector is relatively larger, and the government has had a dominating role in shaping the media system. For example, the print media were initiated by the government and gradually privatised and detached from the government. Deeply embedded in Greenlandic media policy is an understanding that media as a public good needs government support, as it cannot be sustained in a free market where diseconomies of scale apply, especially taking into account the enormous cost of infrastructure development (Ravn-Højgaard, this issue). 
The West Nordic media systems are more vulnerable to external influences than the neighbouring Nordic media systems due to their smaller size. It is therefore likely that micro media systems will be more affected by increased globalisation than "larger small" media systems. They are less robust, much more vulnerable to closures of media outlets, and less able to resist pressure from politicians and business interests. Furthermore, smallness reinforces clientelism, social control, self-censorship, and reluctance to deal with controversial issues and apply critical investigative journalism. Put together, these circumstances may make it more difficult to uphold editorial independence, which may have significant implications for the quality of public debate and dissemination of publicly relevant information in these societies.

The media in the West Nordic countries developed under similar conditions, mostly because of their long historical relationship with Denmark. In the Faroes and Greenland in particular, this relationship can be observed today in the extensive institutional transfer from Denmark, such as professional norms and legal frameworks concerning the media and the media system. Iceland, on the other hand, broke the ties with Denmark in the beginning of the twentieth century. Icelandic scholars have argued that the weak state which emerged was easily susceptible to clientelism, which still impacts the media system (Jóhannsdóttir, 2019; Kristinsson, 2012).

In the Faroes and Iceland, the relationship with Denmark became an important political cleavage with the emergence of national movements by the end of the nineteenth century, and thus also reflected in the partisan press that were either pro- or anti-union with Denmark. In Greenland, national movements emerged a century later. By then, the media institutions were already established by the Danish authorities. This is an example of how similar factors emerging in different social and political contexts in the three West Nordic countries have shaped the media systems in different ways.

With this article, we have provided an overview of the media systems in the West Nordic countries in light of the academic literature on media systems and the Nordic model. However, many questions remain unanswered. What seems most pressing is the impact of the digital revolution on the media landscape in such small media markets. Hence, future research should investigate how digitisation will influence micro-media systems in the West Nordic countries and elsewhere.

\section{References}

Ackrén, M. (2015). The political parties in Greenland and their development. In E. M. Belser, A. Fang-Bär, N. Massüger, \& R. O. Pillai (Eds.), States falling apart? Secessionist and autonomy movements in Europe (pp. 317-335). Bern: Stämpfli Verlag.

Ackrén, M. (2019). Självständighetstanken i Grönland - fiktion eller verklighet? [The Idea of Independence in Greenland - Fiction or Reality?] Politica, 51(4), 469-484.

Ackrén M., \& Lindström B. (2013). Autonomy development, irredentism and secessionism in a Nordic context. In E. Hepburn, \& G. Baldacchino (Eds.), Independence movements in subnational island jurisdictions (pp. 100-117). Abingdon: Routledge. https://doi.org/10.4324/9781315541228

Andreassen, E. (1992). Folkelig offentlighed: En undersøgelse af kulturelle former på Færøerne i 100 år [The public sphere: A study of cultural forms in the Faroes for 100 years]. Copenhagen: Museum Tusculanum.

Axelsson, K., \& Gylfadóttir E. Ý. (2015). Mikilvægi faglegrar blaða- og fréttamennsku og hugleiðingar um paðaðhald sem henni er veitt [Importance of professional journalism]. Lögrétta, 11(1): 46-119.

Bakker, P. (2013). The life cycle of a free newspaper business model in newspaper-rich markets. Journalistica (1), 33-51.

Brüggemann, M., Engesser S., Büchel F., Humprecht E., \& Castro L. (2014). Hallin and Mancini revisited: Four empirical types of western media systems. Journal of Communication, 64(6), 1037-1065. https:// doi.org/10.1111/jcom.12127 
Dalsgarð, A. Ó. (2002). Føroysk blaðsøga 1852-2002 [Faroese newspaper history 1852-2002]. Vestmanna: Sprotin.

Doyle, G. (2002). Media ownership: The economics and politics of convergence and concentration in the UK and European media. London: Sage. http://dx.doi.org/10.4135/9781446219942

Flew, T., \& Waisbord S. (2015). The ongoing significance of national media systems in the context of media globalization. Media, Culture \& Society, 37(4), 620-636. https://doi.org/10.1177/0163443714566903

Friðriksson, G. (2000). Nýjustu fréttir! Saga fjölmiðlunar á Íslandi frá upphafi til vorra daga [Latest News! The History of the Media in Iceland to the Present]. Reykjavik: Iðunn.

Føroysk Miðlafólk. (2017). Miðlar og miðlafólk i Føroyum - ein støðulýsing anno 2017. [Media and journalists in the Faroe Islands - a status report in 2017]. [Unpublished report]. Faroe Islands Journalists' Union.

Gallup. (2020). Topplisti innlend umferd - vika 33, 2020 [Top list-traffic on domestic websites - week 33, 2020]. http://topplistar.gallup.is/

Goetschel, L. (1998). The foreign and security policy interests of small states in today's Europe. In L. Goetschel (Ed.), Small states inside and outside the European Union: Interests and politics (pp. 13-32). Dordrecht: Kluwer Academic Publishers.

Grímsson, Ó. R. (1978). Peripheries and nationalism: The Faroes and Greenland. Scandinavian Political Studies, 1(4), 315-327.

Guðmundsson, B. (2012). The journalist union and the Icelandic media condition: An overview. Reykjavík: Blaðamannafélag Íslands. https://www.press.is/static/files/Utgefidefni/baeklingur2.pdf

Guðmundsson, B. (2015). Sjálfsritskoðun íslenskra blaðamanna [Self-censorship among Icelandic Journalists]. Stjórnmál og stjórnsýsla, 11(1), 55-70.

Guðmundsson, B. (2018). Media in a microstate. In G. Baruchello, J. T. Kristjánsson, K. M. Jóhannsdóttir, \& S. Ingimarsson (Eds.), No one is an island: An Icelandic perspective (pp. 25-39). Newcastle upon Tyne: Cambridge Scholars Publishing.

Guðmundsson, B., \& Kristinsson S. (2019). Journalistic professionalism in Iceland: A framework for analysis and an assessment. Journalism, 20(12), 1684-1703. https://doi.org/10.1177/1464884917695416

Hallin, D. C., \& Mancini P. (2004). Comparing media systems: Three models of media and politics. Cambridge: Cambridge University Press. https://doi.org/10.1017/CBO9780511790867

Hardarson, Ó. T. (2008). Media and politics in Iceland. In J. Strömbäck, M. Ørsten, \& T. Aalberg (Eds.), Communicating politics: Political communication in the Nordic countries (pp. 63-82). Gothenburg: Nordicom, University of Gothenburg.

Humphreys, P. J. (1996). Mass media and media policy in western Europe. Manchester: Manchester University Press.

Humphreys, P. J. (2012). A political scientist's contribution to the comparative study of media systems in Europe: A response to Hallin and Mancini. In N. Just, \& M. Puppis (Eds.), Trends in communications policy research: New theories, methods and subjects (pp. 157-176). Bristol: Intellect.

Hussain, N. (2018). Journalistik i små samfund: Et Studie af journalistisk praksis på grønlandske nyhedsmedier [Journalism in small societies: A study of journalistic practice in Greenlandic news media] [Doctoral dissertation, Roskilde University, Denmark].

Hängi, H. (1998). Small state as a third state: Switzerland and Asia-Europe interregionalism. In L. Goetschel (Ed.), Small states inside and outside the European Union: Interests and politics (pp. 79-96). Dordrecht: Kluwer Academic Publishers.

Jóhannsdóttir, V. (2019). The state of news media in Iceland in the beginning of the 21 st century. [Doctoral dissertation, Doctoral School of Communication and Arts, Roskilde University, Denmark].

Jóhannsdóttir, V. (2020). Commercialization in the IcelandicpPress: An analysis of hard and soft news in major print and online media in Iceland in times of change. Journalism, 21(11), 1762-1778. https://doi. org/10.1177/1464884918768494

Jóhannsdóttir, V., \& Ólafsson, J. G. (2018). The Icelandic media in times of crisis and change. Icelandic Review of Politics and Administration, 14(special issue), 189-201.

Karlsson, R. (2004). Iceland: Mapping the newspaper market 1980-2003. In B. Schneider, \& W. Schütz (Eds.), Europäishe Pressemärkte [European Press Markets] [Special issue of Relation, n.s. 1] (pp. 223-263). Vienna: Austrian Academy of Sciences.

Karlsson, R. (Ed.). (2008). Media and communication statistics: Faroe Islands and Greenland 2008. Gothenburg: Nordicom, University of Gothenburg.

Karlsson, R., \& Broddason P. (2010). Television in Iceland or Icelandic television? In P. Broddason, U. Kivikuru, B. Tufte et al. (Eds.), Norden och världen: Perspektiv från forskningen om medier och kommunikation [The Nordic countries and the world: Perspectives from research on media and communication] (pp. 221-237). Gothenburg: Nordicom, University of Gothenburg.

Karlsson, R., \& Broddason P. (2018). Íslenska fjölmiðlakerfið. Próun og sérkenni [The Icelandic media system: Its development and characteristics]. In V. Árnason, \& H. A. Henrysson (Eds.), Íslenskt lýðrceði: 
Starfsvenjur, gildi og skilningur [Icelandic democracy: Practices, norms, and understanding] (pp. 171-211). Reykjavík: Háskólaútgáfan and Siðfræðistofnun.

Katz, E., \& Wedell, G. (1977). Broadcasting in the third world: Promises and performance. Harvard, Massachusetts: Harvard University Press.

Katzenstein, P. J. (1985). Small states in world markets: Industrial policy in Europe. Ithaca, New York: Cornell University Press.

KNR. (2020). Seer-og lytterundersøgelse [Radio and television audience survey]. https://knr.gl/files/ knr_seer_og_lytterundersogelse_rapport_2019_29012019.pdf

Kohn, M. L. (1989). Introduction. In M. L. Kohn (Ed.), Cross-national research in sociology (pp. 17-31). Newbury Park, California: Sage.

Kolbeins, G. H. (2012). Siðferði og starfshættir íslenskra blaða- og fréttamanna [Ethics and practice of Icelandic journalists]. In S. Eggertsson, \& Á. G. Ásgeirsdóttir (Eds.), Pjóðarspegillinn 2012: Rannsóknir i félagsvisindum XIII [Research in the Social Sciences XIII] (p. 14). Reykjavík: Félagsvíndastofnun Háskóla Íslands. http://hdl.handle.net/1946/13328

Krarup, P. (2017, February 23). Frie medier er i alles intresse-også maghavernes [Free media are in everyone's interest - including those in power]. Nordisk Journalistcenter. https://njc.dk/article/frie-medieralles-interesse-ogsaa-magthavernes/

Kristensen, M. B., Smed, L. S., \& Hansen, T. T. (2020). Integritetsstudie - Grønland, rapportudkast [Integrity study - Greenland, draft report]. Nordic Consulting Group.

Kristinsson, G. H. (2012). Party patronage in Iceland: Rewards and control appointments. In P. Kopecký, P. Mair, \& M. Spirova (Eds.), Party patronage and party government in European democracies (pp. 186205). Oxford: Oxford University Press.

KvF (2018). Public service frágreiðing 2018 [Public service annual report 2018]. Tórshavn, Faroe Islands: Kringvarp Føroya. https://kvf.fo/sites/default/files/KVF ARSFRAGREIDING 2018 Vev.pdf

Inatsisiliorneq Lovgivning. (2004f). Landstingsforordning nr. 6, 2004 om radio- og tv-virksomhed [Regulation on Radio and Television]. http://lovgivning.gl/lov?rid=\{6150FA45-BB7A-4A4E-B7EE-AEF593C19C83\}

Livingstone, S. (2003). On the challenges of cross-national comparative media research. European Journal of Communications, 18(4), 477-500. https://doi.org/10.1177/0267323103184003

Lóður. (2017). Media consumption in the Faroe Islands [Unpublished report].

National Parliament of Iceland. (2013). Lög um Ríkisútvarpið, fjölmiðil í almannapágu, nr. 23, 2013 [Laws on Public Broadcasting Service]. https://www.althingi.is/lagas/nuna/2013023.html

Faroese Law-Site. (2006). Løgtingslóg nr. 61, 2006 um kringvarp, sum seinast broytt við løgtingslóg nr. 163 frá 24. desember 2015 [Broadcasting Laws]. https://ogir.fo/Logtingslog/61-fra-16-05-2006-um-kringvarp-sum-broytt-vid-logtingslog-nr-48-fra-26-mai

Faroese Law-Site. (2017). Løgtingslóg nr. 35, 2017 um miðlastuðul [Laws on media subsidies]. https://www. logir.fo/Logtingslog/35-fra-31-03-2017-midlastudul

Loukacheva, N. (2007). The Arctic promise: Legal and political autonomy of Greenland and Nunavut. Toronto: University of Toronto Press.

Lowe, G. F. \& Nissen C. S. (Eds.). (2011a). Small among giants: Television broadcasting in smaller countries. Gothenburg: Nordicom, University of Gothenburg.

Lowe, G. F., Berg C. E., \& Nissen C. S. (2011b). Size matters for TV broadcasting policy. In G. F. Lowe, \& C. S. Nissen (Eds.), Small among giants: Television broadcasting in smaller countries (pp. 21-42). Gothenburg: Nordicom, University of Gothenburg.

Lund, A. B. (2005). Mediemagt i Norden - et komparativt perspektiv [Media power in the Nordic countries: A comparative perspective]. Nordisk kulturpolitisk tidskrift, 2(1), 203-227.

Lund, A. B. (2007). Media markets in Scandinavia: Political economy aspects of convergence and divergence. Nordicom Review, (Jubliee Issue), 121-134.

Mattoni, A., \& Ceccobelli D. (2018). Comparing hybrid media systems in the digital age: A theoretical framework for analysis. European Journal of Communication, 33(5), 540-557. https://doi. org/10.1177/0267323118784831

Meier, W. A., \& Trappel, J. (1992). Small states in the shadow of giants. In K. Siune, \& W. Treutzchler (Eds.), Dynamics of media politics: Broadcast and electronic media in western Europe (pp. 129-142). London: Sage.

Menntamálaráðuneytið. (2019). Fjölmiðlafrumvarp lagt fram á Alpingi [Media bill submitted in the Parliament]. https:/www.stjornarradid.is/efst-a-baugi/frettir/stok-frett/2019/05/20/Fjolmidlafrumvarp- lagtfram-a-Althingi/

Moe, H., \& Mjøs, O. J. (2013). The arm's length principle in Nordic public broadcasting regulation. In U. Carlsson (Ed.), Public service media from a Nordic horizon: Politics, Markets, programming and users (pp. 75-92). Gothenburg: Nordicom, University of Gothenburg. 
Nechushtai, E. (2018). From liberal to polarized liberal? Contemporary U.S. news in Hallin and Mancini's typology of news systems. The International Journal of Press/Politics, 23(2), 183-201. https://doi. org/10.1177/1940161218771902

Noam, E. (1991). Television in Europe. New York: Oxford University Press.

Nord, L. (2008). Comparing Nordic media systems: North between west and east? Central European Journal of Communication, 1(1), 95-110.

Nordicom. (n.d.-a). Radio channel audience shares 2000, 2005-2019. https://www.nordicom.gu.se/sv/statistik-fakta/mediestatistik

Nordicom. (n.d.-b). Public service TV audience shares 2000-2019. https://www.nordicom.gu.se/sv/statistik-fakta/mediestatistik

Nordicom. (2019). Greenland: Highest media consumption in the Nordic region. https://www.nordicom.gu.se/ en/latest/news/greenland-highest-media-consumption-nordic-region

Nordicom. (2020). Newspaper circulation per thousand inhabitants 2000-2017. https://www.nordicom.gu.se/ en/statistics-facts/media-statistics

Ohlsson, J. (2015). The Nordic media market 2015. Gothenburg: Nordicom, University of Gothenburg.

Ohlsson, J., \& Facht, U. (2017). Ad wars: Digital challenges for ad-financed news media in the Nordic countries. Gothenburg: Nordicom, University of Gothenburg.

Paulsen, N., Ravn-Højgaard S., Simonsen, M., Hussain N., \& Willig I. (2018). Tusagassiuutit 2018 - en kortlagning af de grønlandske medier [Media 2018: Mapping Greenlandic media]. Nuuk: Ilisimatusarfik University of Greenland. https://uni.gl/media/4352533/ dktusagassiuutit2018rapport.pdf

Poulsen, J. (1980). TV-og den farøske kulturs fremtid [Television and future of the Faroese culture]. Tórshavn, Faroe Islands/Aalborg, Denmark: Faroese Scientific Society/Aalborg University Press.

Poulsen, J. (1995). Denmark: From community radio to regional television. In C. Garitaonandia, \& M. de Moragas Spà (Eds.), Decentralization in the global era: Television in the regions, nationalities and small countries of the European Union (pp. 35-41). London: John Libbey.

Puppis, M. (2009). Introduction: Media regulation in small states. International Communication Gazette, 71(1-2), 7-17. https://doi.org/10.1177/1748048508097927

Rask, J. (2017). Frygt fører til selvcensur og dårlig journalistik [Fear leads to self-censorship and bad journalism]. https://njc.dk/frygt-foerer-selvcensur-daarlig-journalistisk/

Ravn-Højgaard, S. (2019). Medier og selvstændighed i Grønland [Media and independence in Greenland]. Politik, 22(1), 67-83. https://doi.org/10.7146/politik.v22i1.114841

Rygaard, J. (2016). KNR - lille tv station blandt giganter: Udfordringer for TV og public service i Grønland [KNR - A small TV station among giants: Challenges for TV and public service in Greenland]. In J. Fink, K. G. Hansen, \& O. Marquaardt (Eds.), Grønland i tal: Kilder og cases gennem 300 år [Greenland in numbers: Sources and cases through 300 years] (pp.173-189). Aarhus, Denmark: Aarhus University Press.

RÚV. (2019). Ársskýrsla RÚV 2019 [RUV's annual report 2019]. Reykjavík: Ríkisútvarpið. https://www. ruv.is/arsskyrsla/

Statistics Faroe Islands. (n.d.). Books and newspapers. https://beta.hagstova.fo/en/society/culture-and-religion/ books-and-newspapers

Statistics Iceland. (n.d.). Media - Statistics. https://statice.is/statistics/society/media/media/

Stenbaek, M. A. (1992). Mass media in Greenland: Politics of survival. In S. H. Riggins (Ed.), Ethnic minority media: An international perspective (pp. 44-62). Newbury Park, California: Sage.

Strömbäck, J., Ørsten, M., \& Aalberg, T. (2008). Political communication in the Nordic countries: An introduction. In J. Strömbäck, M. Ørsten, \& T. Aalberg (Eds.), Communicating politics: Political communication in the Nordic countries (pp. 11-24). Gothenburg: Nordicom, University of Gothenburg.

Syvertsen, T., Enli, G., Mjøs, O. J., \& Moe, H. (2014). The media welfare state: Nordic media in the digital era. Ann Arbor, Michigan: University of Michigan Press. https://www.doi.org/10.3998/ nmw.12367206.0001.001

The World Bank . (n.d.). World Bank open data. https://data.worldbank.org/

Thomsen, N., \& Søllinge, J. D. (1991). De danske aviser 1634-1991, vol. 3: 1918-1991. Copenhagen: Dagspressens Fond/Odense University Press.

Thorhallsson, B. (2018). Studying small states: A review. Small States and Territories, 1(1), 17-34. https:// doi.org/10.1177/0010414014554687

Trappel, J. (1991). Born losers or flexible adjustment? The media policy dilemma of small states. European Journal of Communications, 6(3), 355-371. https://doi.org/10.1177/0267323191006003006

Trappel, J. (2014). Small states and European media policy. In K. Donders, C. Pauwels, \& J. Loisen (Eds.), The Palgrave handbook of European media policy (pp. 239-253). Basingstoke: Palgrave Macmillan. https://doi.org/10.1057/9781137032195

Veenendaal, W. (2015). Politics and democracy in microstates. Abingdon: Routledge. 
Vikør, L. S. (2000). Northern Europe: Languages as prime markers of ethnic and national identity. In S. Barbour, \& C. Carmichael (Eds.), Language and nationalism in Europe (pp. 105-129). Oxford: Oxford University Press.

Wang, Z. (1989). Stjórnmálafrødi [Political science]. Hoyvík, Faroe Islands: Stíðin.

Wang, Z. (1999). Føroyar á vegamóti [The Faroes at a crossroads]. Hoyvík, Faroe Islands: Stíðin.

Weibull, L. (2007). The northern European/democratic corporatist media model countries: Introduction. In G. Terzis (Ed.), European media governance: National and regional dimensions (pp. 55-62). Bristol: Intellect.

Weihe, L. (2017). Den sorte varevogn [The black van]. In P. Lundgren, M. B. Bjerregård, \& O. R. Jensen (Eds.), Den svåra yttrandefriheten: Nordiska roster [The difficult freedom of expression: Nordic voices] (pp. 8-15). Copenhagen: Nordic Council. https://doi.org/10.6027/anp2017-727

Winther, G. (Ed.). (2004). Demokrati og magt i Grønland [Democracy and power in Greenland]. Aarhus, Denmark: Aarhus University Press.

Witschge, T., Anderson, C. W., Domingo, D., \& Hermida A. (2016). Introduction. In T. Witschge, C. W. Anderson, D. Domingo, \& A. Hermida (Eds), The Sage handbook of digital journalism (pp. 1-4). London: Sage.

Ørberg, E. (1984). Avisnarkomanien på Færøerne [Newspaper addiction in the Faroes]. Pressens Arbog, 23(1), 44-49.

Porláksson, B. (2015). Mannorðsmorðingjar? Félagslegar og persónulegar pælingar um stöðu fjölmiðlunar á Íslandi [Reputation murderers? Social and personal thoughts on the media situation in Iceland]. Reykjavík: Salka.

(C) 2021 Nordicom and respective authors. This is an Open Access work licensed under the terms of the Creative Commons Attribution-NonCommercial-NoDerivatives 4.0 International Public licence (CC BY-NC-ND 4.0). To view a copy of the licence, visit https://creativecommons.org/ licenses/by-nc-nd/4.0/ 